\title{
US groups sue over approval of Btcrops ...
}

[WASHINGTON] A coalition of US environmentalists and organic farmers last week filed a lawsuit against the US Environmental Protection Agency (EPA), accusing it of a "blatant disregard" for the law and its own regulations in its approval of the farming of genetically engineered crops.

The 73 plaintiffs, led by Greenpeace, the Washington-based Center for Food Safety, and the International Federation of Organic Agricultural Movements, allege that since 1995 the EPA has approved Bt maize, cotton and potatoes - engineered to produce toxins made by the soil bacterium Bacillus thuringiensis - without fully assessing their environmental safety.

They contend that large-scale planting of the crops will cause insect resistance to the toxins, destroying their value for organic farmers, who have used them for almost forty years.

As a result, they argue, the crops present environmental hazards that should prevent EPA from approving them under federal pesticide law. The groups also claim that EPA disregarded the National Environmental Policy Act by failing to prepare an environmental impact statement analysing the effects of $B t$ crops.

The lawsuit, filed in the US District Court for the District of Columbia, makes the same arguments as the groups' 1997 petition demanding that EPA suspend existing registrations of $B t$ crops and stop issuing new ones until it has comprehensively studied the crops' environmental impact (see Nature 389,317 ; 1997)

The plaintiffs say that the EPA has ignored the petition and that, with the fourth growing season of $B t$ crops now commencing, they must force the agency to take action. "The EPA is essentially studying this issue to death," says Joseph Mendelson, legal

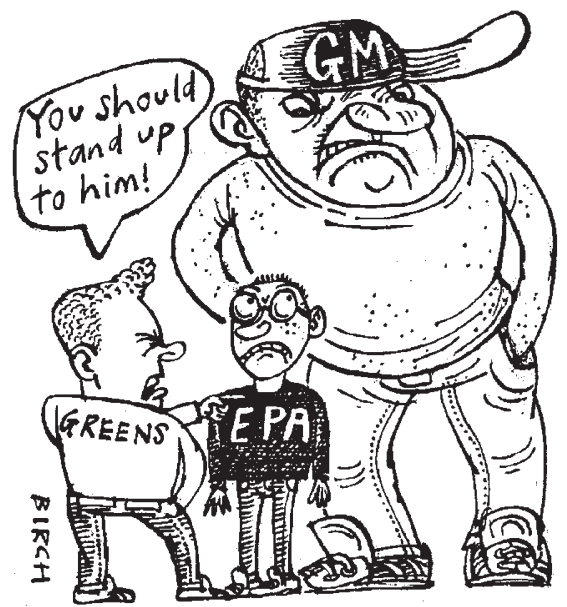

director of the Center for Food Safety and lead counsel on the case.

In a written statement, the EPA said it is careful to ensure that the products it reviews are environmentally sound and beneficial, as required by law: "We believe the actions we've taken with regard to $B t$ will be sustained against this legal challenge."

Industry groups have been quick to attack the lawsuit. Jay Vroom, president of the American Crop Protection Association (ACPA), the major group representing US pesticide manufacturers - including most Bt seed producers - calls it "totally without merit" and argues that "EPA thoroughly assessed the safety of these products".

The group says that $B t$ crops are environmentally friendly: the toxins degrade rapidly and cannot bind in the digestive systems of non-target animals, and the crops spare farm workers exposure to chemical pesticides.

Since the EPA began registering $B t$ crops in 1995, it has approved seven varieties of maize, one of cotton and one of potatoes. The producers include Monsanto, Novartis Seeds, Mycogen, DeKalb and AgrEvo. In

1998, 20 million acres of $B t$ crops were planted in the United States, 15 million of which were maize, just under 20 per cent of US maize acreage.

The agency approves the crops as "plant pesticides" under the federal Fungicide, Insecticide and Rodenticide Act. The plaintiffs contend that EPA has broken this law in approving $B t$ crops, as an approved pesticide must not cause "unreasonable adverse effects" on the environment.

Although insect resistance to the crops has not yet been documented, the activists say they expect widespread resistance to evolve within a few years, because of the large acreages under cultivation and the selection pressure exerted by crops producing $B t$ constantly, as opposed to chemical spraying which was periodic. They also claim that the crops could hasten resistance by transferring the $B t$ trait to neighbouring plants, and argue that some $B t$ toxins may hurt beneficial insects and other non-target organisms.

In response, the ACPA says there is no scientific evidence for gene transfer to neighbouring plants, or for harm to non-target organisms. It adds that EPA requires resistance management plans. But these plans, which rely on areas of non-Bt crops to foster non-resistant, interbreeding insects, have been a prime target of activists. They claim they are inadequate to prevent resistance from emerging (see Nature 388, 817; 1997).

The activists' argument that EPA should have prepared an environmental impact statement for $B t$ crops faces an opposing legal precedent. A 1986 ruling stated that EPA approval of pesticides was not subject to the law requiring environmental impact statements. In that case, an Oregon man had sued to prevent EPA from registering seven herbicides that were sprayed along the road to his wife's farm.

Meredith Wadman

\section{Spain makes trans genic crop produc ers pay into ins urance fund}

[BARCELONA] The Spanish government has decided that companies that produce or plant genetically modified crops must contribute to a 90 million Euro (US\$100 million) insurance fund intended to cover environmental accidents. The move reflects growing calls for tougher restrictions on such crops from opposition political parties, non-governmental organizations, and consumers' associations.

As a result of this pressure, the government's approach to transgenic crops will be debated in parliament this week after two left-wing parties expressed concern that Spain has authorized the planting of genetically modified crops that have not yet been approved in other countries of the European Community.
Environmental issues have become more controversial in Spain since last year's ecological disaster, when thousands of tons of toxic waste spilled into the Doñana national park last April after a retaining wall collapsed at the Aznalcóllar mines in Seville.

One party, the Bloque Nacionalista Gallego, is seeking either a moratorium or a strict limit on the import of such crops. The movement Ecologists in Action, which includes more than 300 environmentrelated organizations, has called for a ban on the 22 experimental field trials by the company Monsanto that have already been approved by the country's biosafety commission.

Concern has been triggered by the high importation of modified crops, especially maize and soya. Between 15,000 and 20,000 hectares are said to have already been planted with such maize from the company Novartis. The number of licences for test plantings has increased from 36 in 1996 to 124 by January of this year.

Transgenic foodstuffs became an issue in Spain in 1996, when seven Greenpeace activists held a protest in Barcelona against a boat containing 45,000 tons of soya, 2 per cent of which was genetically modified.

Cristina Narbona, the environmentcommission spokesperson of the socialist party PSOE, has urged the government to support demands being made at the biodiversity protocol meeting in Colombia to base the protocol on the so-called 'precautionary principle'. Xavier Bosch 